\title{
Localization of Translation Initiation Factors to the Postsynaptic Sites
}

\author{
Myoung-Kwon Choi ${ }^{11}$, Sung Dong Park², In Sick Park ${ }^{3}$ and II Soo Moon ${ }^{1}$ *
}

${ }^{1}$ Department of Anatomy, College of Medicine, Dongguk University, Gyeongju 780-714, Korea

${ }^{2}$ Department of General Thoracic and Cardiovascular Surgery, College of Medicine, Dongguk University, Gyeongju 780-714, Korea ${ }^{3}$ Department of Anatomy, College of Oriental Medicine, Gyeongiu 780-714, Korea

"Present address: School of Biological Science, Seoul National University and National Creative Research Initiative Center for Symbiosystem, Seoul 151-742, Korea

Received October 11, 2011 /Revised November 17, 2011 / Accepted November 17, 2011

\begin{abstract}
Local protein synthesis in neuronal dendrites is important for site-specific regulation of synaptic plasticity. In this study, we investigated whether translation initiation factors (eIFs) are present at the postsynaptic sites. High resolution confocal microscopy showed that the eIF4E and eIF4G (which bind the 5'-terminal mRNA cap), eIF5 (which is important during the 3 ' direction scanning to find an initiation codon), eIF6 (which mediates upregulation of translation by external stimuli), and eIF5A (which mediate translation upregulation under adverse conditions) were localized to the postsynaptic sites. Immunoblot and detergent extraction experiments also indicated that these eIFs were present in the synapse in association with the postsynaptic density (PSD). Our data provide evidence for the strategic positioning of eIFs at the postsynaptic site for initiation of translation in diverse situations.
\end{abstract}

Key words : eIF, neuron, PSD, spine, translation

\section{Introduction}

Neurons communicate through the synapses, which connect neurons into complicated networks, enabling them to receive, process and transmit information. A particular feature of a synapse is that it undergoes continuous modifications, changing efficacy of synaptic transmission. This, so called, synaptic plasticity is considered to be the synaptic basis for learning and memory [4]. Short-term synaptic plasticity occurs by modifications of existing proteins at the synaptic site [12] whereas long-term plasticity such as long-term potentiation and long-term depression requires protein synthesis (see a recent review by Skup [26]).

Local protein synthesis was first proposed in 1965 by David Bodian [5] who was the first to find ribosomes in dendrites. Synapse-associated polyribosomal complexes (SAPC), which are the polyribosomes connected with endoplasmatic reticulum cisterns, were found in hippocampal pyramidal and granular neurons $[27,28,29]$. In addition, dendritic mRNAs were identified by various experimental techniques [26]. The local protein synthesis was finally proved in dendrites which were mechanically and opically sepa-

*Corresponding author

Tel : +82-54-770-2414, Fax : +82-54-770-2447

E-mail : moonis@dongguk.ac.kr rated from neuronal perikarya [1].

mRNAs are translocated to subsynaptic sites in RNA granules, but remain under translational arrest due to the absence of translation factors [18]. Therefore, it is likely that the translation factors are furnished on-site in dendrites. Underneath the postsynaptic membrane are accumulated with proteins such as neurotransmitter receptors, signaling proteins, and cytoskeletal elements. These proteins are assembled into an organized structure called the postsynaptic density (PSD) by a variety of scaffold proteins [24,25]. The PSD is strategically positioned to provide the subsynaptic sites with such translation factors. Indeed, we previously found translation elongation factor-1A (eEF1A) in the PSD of rat cerebral and cerebellar cortex $[8,22]$.

Activity-dependent translation of dendritic mRNAs likely occurs via activation of the general protein synthetic machinery in dendrites. In eukaryotic cells, the rate of translation is primarily regulated at the initiation phase $[20,31]$. The initiation recruits the $40 \mathrm{~S}$ small ribosomal subunit to the $5^{\prime}$-terminal mRNA cap, the methylated guanine moiety m7GpppN (where $\mathrm{N}$ is the first transcribed nucleotide). The cap binding of eukaryotic initiation factor $4 \mathrm{E}$ (eIF4E) and another initiation factor, eIF4G, is essential for translation $[13,31]$. In this study we investigated the presence of various eIFs in the PSD by immunoblots and immunocytochemistry (ICC) of cultured rat hippocampal neurons. 


\section{Materials and Methods}

\section{Antibodies}

The following antibodies were used at the indicated dilutions: Mouse monoclonals eIF4E, eIF4G, eIF5, eIF5a, and eIF6 (1:1,000 for immunoblot, 1:500 for ICC; all from BD Biosciences), rabbit anti-synaptophysin (SNP; 1:500; Chemicon), chicken polyclonal PSD-95 (1:1,000, antiserum UCT-C1, a kind gift from Walikonis R, Univ. Conn., USA).

\section{Subcellular fractionation and detergent extraction}

One-Triton PSD fractions were prepared from adult rat ( $250 \mathrm{~g}$, Sprague-Dawley) forebrains by washing synaptosome-enriched fractions with $0.5 \%$ Triton X-100, as previously described [7]. In detergent extraction experiments, One-Triton PSD fractions were extracted again at $4^{\circ} \mathrm{C}$ with $1.0 \%$ Triton or $1.0 \%$ n-octyl- $\beta$-D-glucoside (OG) for $15 \mathrm{~min}$ or with $3 \% N$-lauroylsarcosine [sarcosyl (Sarc)] for $10 \mathrm{~min}$. Thereafter, the pellet and supernatant were separated by centrifugation at 201,800 $\mathrm{g}$ for $1 \mathrm{hr}$ at $4^{\circ} \mathrm{C}$, and the pellet was resuspended in $40 \mathrm{mM}$ Tris- $\mathrm{HCl}(\mathrm{pH} 8.0)$.

\section{Cell culture}

Hippocampi from Sprague-Dawley rat pups at embryonic day 18 (E18) or E19 were dissected, dissociated by trypsin treatment and mechanical trituration. Cells were plated onto 12-mm diameter polylysine/laminin-coated glass coverslips [6,12]. Cells were initially plated in Neurobasal medium supplemented with B27 (Invitrogen, USA), $25 \mu \mathrm{M}$ glutamate, and $500 \mu \mathrm{M}$ glutamine, and fed 5 days after plating, and weekly thereafter with the same media (without added glutamate) containing $1 / 3(\mathrm{v} / \mathrm{v})$ 'conditioned' Neurobasal media by incubating for $24 \mathrm{hr}$ on astrocyte cultures [12]

\section{Immunocytochemistry (ICC)}

On 21 days in vitro (DIV), coverslips were rinsed briefly in Dulbecco's phosphate-buffered saline (D-PBS; Invitrogen) and fixed by a sequential paraformaldehyde/methanol fixation procedure [incubation in $4 \%$ paraformaldehyde in PBS (20 mM sodium phosphate buffer, $\mathrm{pH} 7.4,0.9 \% \mathrm{NaCl}$ ) at room temperature (RT) for $10 \mathrm{~min}$ followed by incubation in methanol at $-20^{\circ} \mathrm{C}$ for $20 \mathrm{~min}$ ] [27]. ICC was performed with indicated primary and secondary [Alexa Fluor 488-conjugated goat anti-mouse, Alexa Fluor 568-conjugated goat anti-rabbit, Alexa Fluor 647-conjugated goat anti-chicken IgG (each diluted 1:1,000; Molecular Probes, Inc., Eugene, OR)] as described [27].

\section{Laser-scanning confocal microscopy}

Confocal images $(1,024 \times 1,024$ pixels $)$ were acquired using a 100X oil-immersion lens on a Leica TCS SP2 Confocal System with laser lines at 488,543, and $633 \mathrm{~nm}$, and processed with the use of Adobe Systems Photoshop 5.0 software.

\section{Results and Discussion}

High resolution confocal images show that elFs are localized to the postsynaptic site

\section{eIF4E and eIF4G}

To prove postsynaptic localization we first performed ICC to localize various eIFs in the neuron. For this purpose, rat hippocampal dissociated cultures (DIV 21) were triple-labeled with a specific anti-eIF, anti-PSD95 (a postsynaptic marker), and anti-synaptophysin (SNP; a presynaptic marker). PSD95-immunoreactive (IR) signals formed clusters along neuronal dendrites (Fig. 1, PSD95). The SNP-IR also formed similar clusters. However, the two kinds of clusters were differentially distributed: The PSD95 ones were distributed throughout the dendritic shaft whereas those of SNP were usually positioned at the periphery of the shaft. It makes sense that the SNP clusters were formed outside of the shaft because SNP is a major synaptic vesicle protein in the presynaptic terminals. Theoretically, the two kinds of clusters would juxtapose each other. Indeed, the merge of PSD95 and SNP-IR images showed that they were frequently positioned next to each other (Fig. 1, arrowheads in the bottom inserts; green + red). This result shows that the antibodies were very specific, and that the general experimental procedure was integral.

The IR-signals of eIFs, in general, also formed clusters throughout the somatodendritic domains. The eIF4E was already reported to be enriched in the postsynaptic sites [1]. Our data also showed that the eIF4E-IR formed clusters, many of which were juxtaposed to SNP clusters and overlapped with PSD95 (Fig. 1A). Statistical analysis showed that the co-localization rate of eIF4E with PSD95 was $42 \pm 14 \%$ (counted eIF4E clusters=108). Previously, it was reported that the eIF-4E-immunoreactivity was localized to the post- 
synaptic sites, especially to the microvesicle-like structures underneath the postsynaptic membrane in the spine, and some of which were localized in close proximity to PSD [1]. Therefore, the eIF4E-IR served as a good control for the integrity of the experimental procedure. Considering the importance in the initiation control, we have chosen 4 more eIFs (eIF4G, eIF5, eIF5a, eIF6) to test their localization at the postsynaptic site. Firstly, the eIF4G was chosen because it plays a critical role in the initiation step. eIF4G is an essential and multifunctional scaffold protein [10]. It is a subunit of the heterotrimeric eIF4F complex, which binds the mRNA $5^{\prime}$ cap and facilitates ribosome to join the mRNA [16]. eIF4G interacts with other cap-binding factors [eIF4E, eIF4A, and the poly $(\mathrm{A})$ binding protein $(\mathrm{PABP})]$ and stimulates initiation factor recruitment $[14,16]$. As shown in Fig. 1B (eIF4G), the eIF4G-IR signals formed clusters throughout the somatodendritic domain. The general distribution profile in the dendrite was similar to that of eIF4E positioning throughout the dendritic shaft with some protruding out. Like eIF4E, many eIF4G-IR clusters overlapped with PSD95, and neighbored to those of SNP, a presynaptic marker. Statistical analysis showed that the co-localization rate of eIF4G with PSD95 was $63 \pm 13 \%$ (counted eIF4G clusters=113). Therefore, this result indicates that eIF4G locates to the postsynaptic sites. Since the PABP - eIF4G interaction is vital for efficient translation [16], localization of eIF4G at the postsynaptic site is likely to be strategically important for synaptic regulation.

\section{eIF5}

Next, we investigated on eIF5 which hydrolyses the eIF2-bound GTP by the GAP activity of eIF5. eIF2 is a GTP-binding protein that deliver initiator methionyl tRNA to the ribosome. eIF2 binds Met-tRNAi only when in its active GTP-bound form. Following mRNA binding at the $5{ }^{\prime}$ end, an eIF2-binding protein PIC migrates in a $3^{\prime}$ direction (scanning) to find an initiation codon [15]. GTP hydrolysis to GDP+Pi is triggered by the GAP activity of eIF5, promoting release from the ribosome/mRNA/Met-tRNAi complex of an eIF2 - GDP/eIF5 complex [30]. In this release step, eIF5 acts as a GDI (GDP dissociation inhibitor) preventing premature GDP release [15]. For subsequent rounds of translation initiation to occur eIF2 must be reactivated to allow rebinding of Met-tRNAi. Hence, eIF5 GDI is necessary for tight control of translation initiation. As shown in Fig. 1C, the eIF5A-IR signals formed clusters throughout the somatodendritic domain. The general distribution profile in the dendrite was similar to that of eIF4E and eIF4G positioning throughout the dendritic shaft with some protruding out. Many eIF5-IR clusters overlapped with PSD95, a postsynaptic marker, whereas they neighbored to those of SNP, presynaptic markers. Statistical analysis showed that the co-localization rate of eIF5 with PSD95 was $64 \pm 15 \%$ (counted eIF5 clusters=128). Therefore, this result indicates that eIF5 locates to the postsynaptic sites.

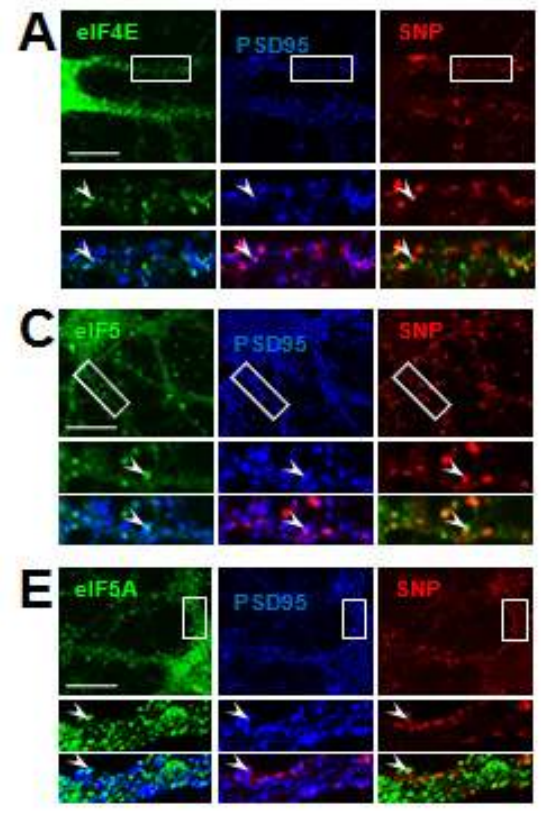

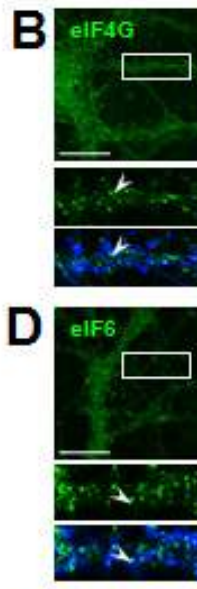
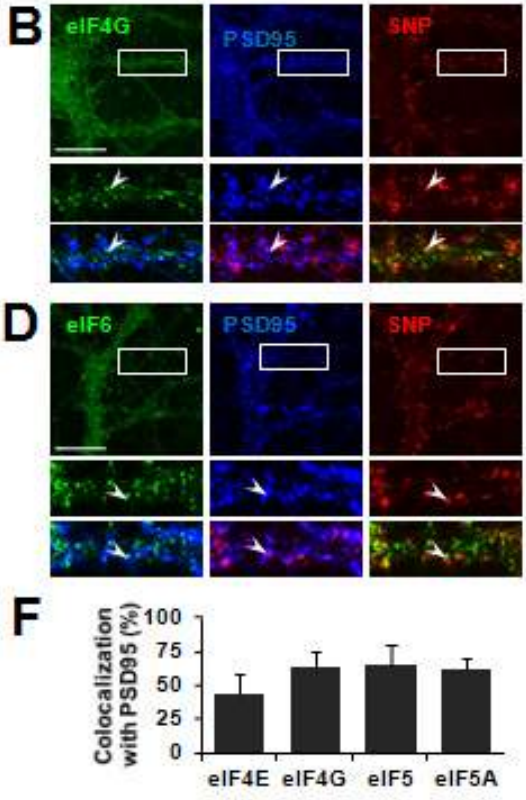

Fig. 1. Confocal microscopic images showing rat hippocampal dissociated cultures (DIV 21), which were triple-labeled with antibodies against the indicated eIF, PSD95, and synaptophysin (SNP). The boxed area was enlarged at the bottom of each panel and merge images in various combinations were also shown. An example of juxtapositioning was marked with arrowheads. (A) eIF4E, (B) eIF4G, (C) eIF5, (D) eIF6, (E) eIF5A. (F) Statistics. Colocalization of each eIF with PSD95 was expressed in the \% of total eIF clusters (mean \pm SD). Scale bar, $15 \mu \mathrm{m}$. 


\section{eIF6}

Next, we investigated on eIF6, which binds to $66 \mathrm{~S}$ large preribosomal subunits during the process of ribosome biogenesis in the nucleus and prevents the premature association with $40 \mathrm{~S}$ ribosomal subunits to form $80 \mathrm{~S}$ complexes. In the cytoplasm, eIF6 acts as an anti-association factor by binding free $60 \mathrm{~S}$ subunits and keeping ribosomes dissociated - either after their biogenesis or during their recycling from translated mRNA [21]. Therefore, eIF6 can mediate a continuum between the maturation of the ribosome in the nucleus and translation in the cytoplasm. The eIF6 is unique in that its expression is controlled by growth factors and/or mitogens, and positively regulates translation [9]. As shown in Fig. 1D, the eIF6-IR signals formed clusters throughout the somatodendritic domain. The general distribution profile in the dendrite was similar to that of eIF4E, eIF4G, and eIF5 positioning throughout the dendritic shaft with some protruding out. As other eIFs shown above, many eIF6-IR clusters overlapped with PSD95, a postsynaptic marker, and neighbored to SNP, a presynaptic marker. Statistical analysis showed that the co-localization rate of eIF6 with PSD95 was $43 \pm 10 \%$ (counted eIF6 clusters=110). Presence of eIF6 at the postsynaptic sites strongly suggests that local translation is upregulated by external stimuli such as the presynaptic activity and neurotrophic factors.

\section{eIF5A}

eIF5A was first described as a ribosome-associated translation initiation factor purified from rabbit reticulocytes [3]. In Saccharomyces cerevisiae, depletion of eIF5A reduced global protein synthesis by $\sim 30 \%$ [17]. In addition to translation initiation, eIF5A has been implicated in multiple cellular functions including mRNA decay, cell cycle progression, cell survival, retroviral infection and translation elongation (see references in $\mathrm{Li}$ et al. [19]). A recent report by $\mathrm{Li}$ et al. [19] indicated that eIF5A has modest effects on normal protein synthesis, but is required for the rapid polysome disassembly and translational repression in cells subjected to oxidative stress. As shown in Fig. 1E, the eIF5A-IR signals exhibited a subcellular distribution profile similar to the above eIFs, forming clusters throughout the somatodendritic domain, overlapping with PSD95, and neighboring to SNP. Statistical analysis showed that the co-localization rate of eIF5A with PSD95 was $61 \pm 9 \%$ (counted eIF5A clusters=130). Therefore, this result indicates that eIF5A locates to the postsynaptic sites. eIF5A is a non-essential translation elongation factor in mammalian cells. However, it is proposed that eIF5A may play an important role in reprogramming protein synthesis in stressed cells, a process that can make cells survive under adverse conditions. Therefore, the presence of eIF5A at the postsynaptic sites suggests that a similar defense machinery is localized at the synapse.

elFs are enriched in, and associated with, the postsynaptic density (PSD)

So far, we have shown morphological evidence that eIFs localize to the postsynaptic sites. To further confirm their postsynaptic localization we performed biochemical analyses. Firstly, we carried out immunoblotting of subcellular fractions. As shown in Fig. 2, each antibody recognized an antigen which exhibits a predominant IR signals at the position of predicted molecular size in the SDS-PAGE. The immunoblot signals were detected in the brain homogenate (BH), synaptosome (Syn) and PSD (PSD) fractions with decreasing signals. This indicates that the eIFs are present in the PSD but are not specifically enriched there. This can be understood because eIFs are cytosolic proteins which mainly locate to the soma. However, the decreases in the intensity of IR signals of Syn and PSD were small, indicating that they are concentrated locally at the postsynaptic membrane.

To gain further insight into the relationship between eIFs and PSD we carried out detergent extraction experiments (Fig. 3). Except eIF4E, mild non-ionic detergents n-octylglucoside (OG; 1.0\%) and Triton X-100 (Triton, 1.0\%) were not efficient in solubilizing eIFs, but a harsh detergent sarcosyl

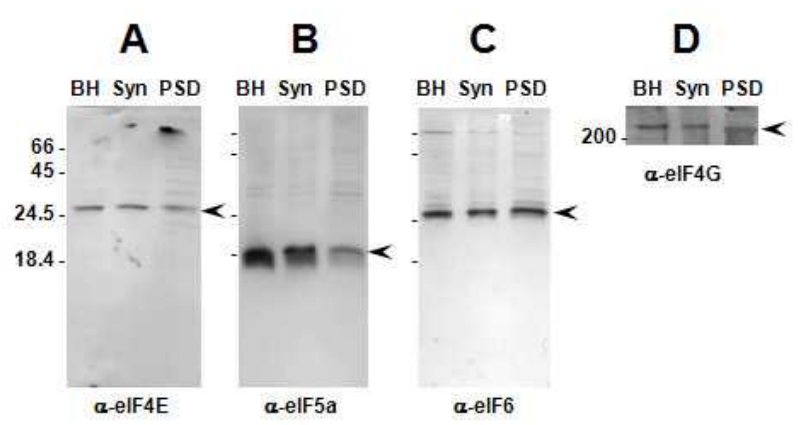

Fig. 2. Immunoblots showing presence of eIFs in the PSD fraction. Forty micrograms of brain homogenate $(\mathrm{BH})$, synaptosome (Syn), and One-Triton PSD (PSD) fractions were immunoblotted with antibodies against indicated eIFs. The position of each eIF was marked with arrowheads. Molecular sizes (in $\mathrm{kDa}$ ) are indicated on the left of each panel. 


\section{$\frac{\mathrm{OG}}{\mathrm{P} \& \mathrm{~S}} \frac{\text { Triton }}{\mathrm{P} \mathrm{s}} \frac{\mathrm{Sarc}}{\mathrm{P} \mathrm{s}} \frac{\mathrm{NaCl}}{\mathrm{P} \mathrm{s}}$

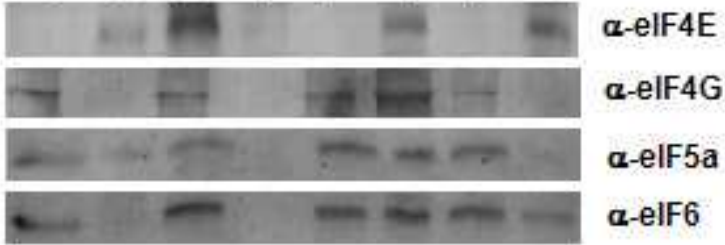

Fig. 3. Detergent extraction experiments showing association characteristics of eIFs with the PSD 'core'. One-Triton PSD fractions were extracted with n-octyl- $\beta$-D-glucoside (OG, 1.0\%), Triton X-100 (Triton, 1.0\%), sarcosyl (Sarc, $3.0 \%)$, and $\mathrm{NaCl}(1.0 \mathrm{M})$. Soluble $(\mathrm{S})$ and insoluble pellet (P) fractions were separated by centrifugation and immunoblotted with indicated antibodies.

(Sarc, 3\%) efficiently solublized them. Salt $(1.0 \mathrm{M} \mathrm{NaCl})$ was not efficient in solubilizing eIFs except eIF4E. These data suggest that eIFs are tightly associated with the PSD 'core'. The biochemical characteristics of eIF4E were different from other eIFs. This phenomenon could derive from the localization of eIF4E. Previously, Asaki et al. [1] reported that the eIF-4E-immunoreactivity was localized to the microvesicle-like structures underneath the postsynaptic membrane in the spine, although some of which were localized in close proximity to PSD. Since eIF4E is localized at the membrane of the microvesicles, they would be efficiently solublized even by mild detergents.

In summary, we investigated whether eIFs are present at the postsynaptic sites. We selected eIFs belonging to diverse functional classes. The first group involves eIF4E and eIF4G which plays critical roles in the initial step of translation initiation. The second one eIF5 is important in the next step of translation initiation, keeping the initiation complex on the mRNA during the $3^{\prime}$ direction scanning to find an initiation codon. The third one is eIF6, which mediates translation upregulation by external stimuli. The last one is eIF5A, which is important in the cell survival under adverse conditions. Our cell biological and biochemical data support that all these tested eIFs are present at the postsynaptic sites indicating that local translation at the postsynaptic sites can occur under various situations. Further studies using electron microcopy are necessary to precisely localize the eIFs in the synapse.

\section{Acknowledgment}

This research was supported by the research program of
Dongguk University to ISP.

\section{References}

1. Aakalu, G., W. B. Smith, N. Nguyen, C. Jiang, and E. Schuman. 2001. Dynamic visualization of local protein synthesis in hippocampal neurons. Neuron 30, 89-502.

2. Asaki, C., N. Usuda, A. Nakazawa, K. Kametani, and T. Suzuki. 2003. Localization of translational components at the ultramicroscopic level at postsynaptic sites of the rat brain. Brain Res. 972, 168-176.

3. Benne, R. and J. W. Hershey. 1978. The mechanism of action of protein synthesis initiation factors from rabbit reticulocytes. J. Biol. Chem 253, 3078 - 3087.

4. Bliss, T. V. and G. L. Collingridge. 1993. A synaptic model of memory: long-term potentiation in the hippocampus. Nature 361, 31-39.

5. Bodian, D. 1965. A suggestive relationship of nerve cell RNA with specific synaptic sites. Proc. Natl. Acad Sci. USA 53, 418-425.

6. Brewer, G. J., J. R. Torricelli, E. K. Evege, and P. J. Price. 1993. Optimized survival of hippocampal neurons in B27-supplemented Neurobasal, a new serum-free medium combination. J. Neurosci. Res. 35, 567-576.

7. Cho, K. O, C. A. Hunt, and M. B. Kennedy. 1992. The rat brain postsynaptic density fraction contains a homolog of the Drosophila discs-large tumor suppressor protein. Neuron 9, 929-942.

8. Cho, S. J., J. S. Jung, B. H. Ko, I. Jin, and I. S. Moon. 2004. Presence of translation elongation factor-1A (eEF1A) in the excitatory postsynaptic density of rat cerebral cortex. Neurosci Lett. 366, 29-33.

9. Gandin, V., A. Miluzio, A. M. Barbieri, A. Beugnet, H. Kiyokawa, P. C. Marchisio, and S. Biffo. 2008. Eukaryotic initiation factor 6 is rate-limiting in translation, growth and transformation. Nature 455, 684-688.

10. Gingras, A. C., B. Raught, and N. Sonenberg. 1999. eIF4 initiation factors: effectors of mRNA recruitment to ribosomes and regulators of translation. Annu. Rev. Biochem 68, 913-963.

11. Goelet, P., V. F. Castellucci, S. Schacher, and E. R. Kandel. 1986. The long and the short of long-term memory - a molecular framework. Nature 322, 419-422.

12. Goslin, K., H. Assmussen, and G. Banker. 1998. Rat hippocampal neurons in low density culture, pp. 339-370. In Banker, G. and K. Goslin (eds.), Culturing Nerve Cells, 2nd eds., MIT Press, Cambridge, MA.

13. Gross, J. D., N. J. Moerke, von der T. Haar, A. A. Lugovskoy, A. B. Sachs, J. E. McCarthy, and G. Wagner. 2003. Ribosome loading onto the mRNA cap is driven by conformational coupling between eIF4G and eIF4E. Cell 115, 739-750.

14. Imataka, H., A. Gradi, and N. Sonenberg. 1998. A newly identified N-terminal amino acid sequence of human eIF4G binds poly(A)-binding protein and functions in poly(A)-dependent translation. EMBO J. 17, 7480-7489. 
15. Jennings, M. D. and G. D. Pavitt. 2010. eIF5 has GDI activity necessary for translational control by eIF2 phosphorylation. Nature 465, 378-381.

16. Kahvejian, A., Y. V. Svitkin, R. Sukarieh, M. N. M'Boutchou, and N. Sonenberg. 2005. Mammalian poly(A)-binding protein is a eukaryotic translation initiation factor, which acts via multiple mechanisms. Genes Dev. 19, 104-113.

17. Kang, H. and J. W. Hershey. 1994. Effect of initiation factor eiF5A depletion on protein synthesis and proliferation of Saccharomyces cerevisiae. J. Biol. Chem 269, 3934-3940.

18. Krichevsky, A. M. and K. S. Kosik. 2001. Neuronal RNA granules: a link between RNA localization and stimulation-dependent translation. Neuron 32, 683-696.

19. Li, C. H., T. Ohn, P. Ivanov, S. Tisdale, and P. Anderson. 2010. eIF5A promotes translation elongation, polysome disassembly and stress granule assembly. PLoS One 5, e9942.

20. Mathews, M. B., N. Sonenberg, and J. W. B. Hershey. 2000. Origins and principles of translational control, pp. 1-32, In Sonenberg, N., J. W. B. Hershey, and M. B. Mathews. (eds.), Translational Control in Gene Expression. Cold Spring Harbor Laboratory Press, New York, NY.

21. Miluzio, A., A. Beugnet, V. Volta, and S. Biffo. 2009. Eukaryotic initiation factor 6 mediates a continuum between $60 \mathrm{~S}$ ribosome biogenesis and translation. EMBO Rep. 10, $459-465$.

22. Moon, I. S., S. J. Cho, J. S. Jung, I. S. Park, D. K. Kim, J. T. Kim, B. H. Ko, and I. Jin. 2004. Presence of translation elongation factor-1A in the rat cerebellar postsynaptic density. Neurosci. Lett. 362, 53-56.
23. Moon, I. S., S. J. Cho, I. Jin, and R. Walikonis. 2007. A simple method for combined fluorescence in situ hybridization and immunocytochemistry. Mol. Cells 24, 76-82.

24. Okabe, S. 2007. Molecular anatomy of the postsynaptic density. Mol. Cell Neurosci. 34, 503-518.

25. Sheng, M. and C. C. Hoogenraad. 2007. The postsynaptic architecture of excitatory synapses: a more quantitative view. Annu. Rev. Biochem. 76, 823-847.

26. Skup, M. 2008. Dendrites as separate compartment - local protein synthesis. Acta Neurobiol. Exp. 68, 305-321.

27. Steward, O. 1983. Alterations in polyribosomes associated with dendritic spines during the reinnervation of the dentate gyrus of the adult rat. J. Neurosci. 3, 177-188.

28. Steward, O. and B. Fass. 1983. Polyribosomes associated with dendritic spines in the denervated dentate gyrus: evidence for local regulation of protein synthesis during reinnervation. Prog. Brain Res. 58, 131-136.

29. Steward, O. and W. B. Levy. 1982. Preferential localization of polyribosomes under the base of dendritic spines in granule cells of the dentate gyrus. J. Neurosci. 2, 284-291.

30. Unbehaun, A., S. I. Borukhov, C. U. Hellen, and T. V. Pestova. 2004. Release of initiation factors from $48 \mathrm{~S}$ complexes during ribosomal subunit joining and the link between establishment of codon-anticodon base-pairing and hydrolysis of eIF2-bound GTP. Genes Dev. 18, 3078-3093.

31. von der Haar, T., J. D. Gross, G. Wagner, and J. E. McCarthy. 2004. The mRNA cap-binding protein eIF4E in post-transcriptional gene expression. Nat. Struct. Mol. Biol. $11,503-511$.

\section{초록 : 신경세포 연접후 위치에 단백질합성 해석시작인자(elF)들의 존재}

최명권 ${ }^{1} \cdot$ 박성동 $^{2} \cdot$ 박인식 $^{3} \cdot$ 문일수 $^{*}{ }^{*}$

( ${ }^{1}$ 동국대학교 의과대학 해부학교실, ${ }^{2}$ 흥부외과학교실, ${ }^{3}$ 동국대학교 한의과대학 해부학교실)

신경세포의 연접후 위치에서 단백질합성은 국소적 연접가소성의 조절에 중요한 역할을 한다. 본 연구에서는 연접후 위치에 eIF들이 존재하는지를 배양한 흰쥐해마신경세포의 면역세포화학적 염색과 immunoblot, 그리고 세제세척실험으로 알아보았다. 단백질해석 시작단계의 초기에 중요한 역할을 하는 eIF4E와 eIF4G, 개시코돈을 찾는 단계에서 중요한 $\mathrm{eIF5}$, 외부자극에 의하여 합성을 시작하게 하는 $\mathrm{eIF6}$, 그리고 불리한 환경에서 해석의 효율 을 높여주는 eIF5A 들은 모두 해마신경세포의 연접후에 위치함을 배양한 해마신경세포를 다중초점형광현미경으 로 관찰할 수 있었다. 또한 Immunoblot 실험에서도 이들은 연접후치밀질(PSD) 분획에서 검출되었으며, 여러 가 지 세제에 의하여 PSD로부터 잘 떨어지지 않는 것으로 보아 PSD와 강하게 결합하고 있음을 알 수 있었다. 본 연구결과는 여러 가지 eIF들이 연접후에 위치하여 다양한 상황에서 단백질합성을 시작하게 할 수 있음을 시사한 다. 